The binary programme is being opposed by a small number of congressmen concerned chiefly over the possibly damaging effects of a massive new chemical weapons programme on the Geneva CCD talks, and they seem to be picking up some influential support from a few conservatives connected with military affairs-a sign, perhaps, of the way the wind is blowing, is that the House Armed Services Committee recently voted to cut about $\$ 1.9$ million from the Pentagon's request for research and development related to binaries (this, it should be noted, would be an entirely separate demand from the demand for production funds).

One particularly effective argument, which surfaced during the House Foreign Affairs Committee hearing earlier this month, is that the Administration is now conducting an "urgent review" of the binary programme itself, and that Congress should therefore delay approving the Pentagon's request for production funding, at least until the National Security Council has decided whether or not the Administration is actually in favour of the programme. At present the Congress is placed in the position of deciding whether or not to provide money for a programme which may be killed off by executive fiat at some future date-a situation that would arise only in the highly sensitive region of defence spending, and which gives substance, to the view that there is little executive scrutiny of the Pentagon's annual demands before their submission to the Congress.

Although that argument may ultimately carry most weight in the Congress, it became clear during the House hearings that the binary programme could well be in trouble for a variety of other reasons, and that there is a division of opinion actually within the Administration on the merits of pushing ahead with a chemical weapons programme of any variety at the current stage of the Geneva talks. The NSC review of the binary programme will inevitably be subjected to some critical 'input' from the Arms Control and Disarmament Agency, which has admitted serious disquiet over the possibility of a probinary decision damaging-perhaps fatally -the CCD discussions. Dr Fred Ikle, Director of ACDA for the past year, said, under heavy questioning from the commitee chairman last week that: "It is my judgment, based on arms control considerations-and this is a personal view-that at this time the pros and cons come out in favour of not going into production (of binaries)".

The military view, as expressed by $\mathrm{Mr}$ Jordan, is that present nerve gas stockpiles "do not fully provide the capability we believe is necessary to adequately support all United States forces in case chemical warfare is used against us. Binaries," he said, "provide significant operational and safety advantages over any other known approach which could have been selected for modernisation."

The situation is therefore the familiar one of the official United States negotiating position being in favour of disarmament, yet at the same time the Pentagon is pushing for a new weapons programme. According to Representative Patricia Schroeder, who attended the CCD talks last year as an official United States observer, "Where many nations last summer simply regarded the United States as having assigned a rather low priority to CCD activities, by mid-March, as the 26 reconvened, one of the more influential western delegates, Dr Alfonso Garcia Robles, leader of the Mexican delegation, went so far as to suggest that we plan to trigger a chemical arms race."

Another factor which has recently been injected into the binary debateand one which could ultimately prove decisive-is the potential opposition of
Western European Governments to the programme. In fact, $\mathrm{Mr}$ Leon Sloss, Assistant Secretary of State for Political-military Affairs, admitted under questioning by the House Foreign Affairs Committee that the binary programme is running into some diplomatic difficulties.

The reason is simple. Binary weapons make sense only if they are deployed in forward positions, ready to retaliate against an aggressor who initiates chemical warfare. In other words, nerve gases stored in depots in the United States would be of little use as quick response weapons against the Soviet Union, and the only place it makes sense to keep the weapons is in Europe. Sloss refused to discuss the subject in open session, but admitted that any attempt to expand nerve gas stocks in Western Europe would run into difficulty.

Some British observers feel that the outcome of all this will be that the Adminstration will decide that the programme is not worth the diplomatic storm that it may cause and that it will eventually be stopped. But sources on Capitol Hill, while remaining moderately optimistic, believe that the issue is far from decided.

\title{
Another refusal to join the NAS
}

FOR most American scientists, election to membership of the National Academy of Sciences (NAS) is regarded as an accolade second only, perhaps, to being awarded the Nobel Prize. But during the past four years, two scientists have resigned from the august body, and two others have refused to accept membership when it was offered to them. The chief complaint all four have raised is the academy's close involvement with the research programmes of the Department of Defense.

The latest to decline association with the academy is Richard Levins, a mathematical biologist from the University of Chicago, who was elected to the Academy at the general meeting in April. Levins turned down the offer in a letter dated May 10, stating that his "first and most urgent concern is the continuing participation of the academy in military matters".

Levins also sharply criticised the policies of the academy's President, Philip Handler, but he argued that the organisation's connections with the military are "not the result of a perversion of the academy's nature by Phillip [ric] Handler or his predecessors, but of a faithful interpretation of its charter and traditions".

The academy's charter, received from President Abraham Lincoln, specifically gives it the role of advising the government, and Levins therefore argues that it would be self defeating to accept membership in the academy and then try to reform from the inside. His letter states: "I cannot hope to remedy this situation by planning with other colleagues to replace Mr Handler with a more liberal president, or by manoeuvring to restore the NAS to its true mission: it is performing its true mission, and $I$ find that mission repugnant."

Levins specifically attacks Handler for trying to "weaken any criticisms of the military, as he did in his covering letter (to the academy's report on herbicide damage in Vietnam), where among other things he dismisses the evidence of damage to human health and of death caused by herbicides."

For his part, Handler claims that the amount of classified work undertaken by the academy has declined during the past few years. He stated in his annual report to the membership that about $5 \%$ of the funds funnelled through the academy this year were concerned with that resulted in the printing of classified reports.

Be that as it may, Levins and others who have attacked the academy for its association with the military would like to see the organisation completely sever its ties with the Department of Defense. In refusing to accept membership of the academy, Levins is following a precedent set by $\mathrm{Dr}$ George Field, a Harvard astronomer. 